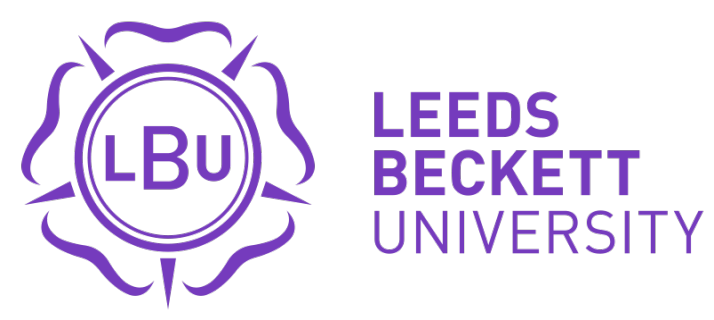

Citation:

Burroughs, RM (2015) Gaskell on the waterfront: Leisure, labor, and maritime space in the midnineteenth century. In: Place Progress and Personhood in the Works of Elizabeth Gaskell. Ashgate (Routledge), 11 - 22. ISBN 9781472429636

Link to Leeds Beckett Repository record:

https://eprints.leedsbeckett.ac.uk/id/eprint/1700/

Document Version:

Book Section (Accepted Version)

Uploaded by permission of Ashgate (Keith Towndrow)

The aim of the Leeds Beckett Repository is to provide open access to our research, as required by funder policies and permitted by publishers and copyright law.

The Leeds Beckett repository holds a wide range of publications, each of which has been checked for copyright and the relevant embargo period has been applied by the Research Services team.

We operate on a standard take-down policy. If you are the author or publisher of an output and you would like it removed from the repository, please contact us and we will investigate on a case-by-case basis.

Each thesis in the repository has been cleared where necessary by the author for third party copyright. If you would like a thesis to be removed from the repository or believe there is an issue with copyright, please contact us on openaccess@leedsbeckett.ac.uk and we will investigate on a case-by-case basis. 


\section{Gaskell on the Waterfront: Leisure, Labour and Maritime Space in the Mid-Nineteenth}

\section{Century}

\section{Rob Burroughs}

\section{Leeds Metropolitan University, UK}

As a writer of place, Elizabeth Gaskell's critical and popular reputation is based on her fictions of the city, provincial town and countryside. Coastal settings and seafaring characters nonetheless recur, albeit often in the margins, in both her novels and shorter fiction, and in Sylvia's Lovers (1863) the maritime sphere is central. Recent studies have examined Sylvia's Lovers and the mutiny subplot of North and South (1855) in the context of eighteenth- and nineteenth-century naval history (d' Albertis Dissembling Fictions 103-36; Peck 131-39; Morse; Lewis). On the whole, though, when critics note Gaskell's interest in sailors and the sea, they tend to do so in biographical terms of the nautical careers of male members of her immediate family_above all her elder brother, John Stevenson, a merchant seaman apparently lost at sea when she was 18 . Whereas Gaskell is routinely credited with deliberate and conscientious examination of urban society and history, criticsassociate her writing of the maritime sphere with the realm of the personal, even the unconscious. Deidre d'Albertis, for instance, writes that through the mysterious disappearance and remarkable return of sea voyagers 'Gaskell sought to repair imaginatively a rupture in her own family that could never be healed, or-if the letters we possess are any indication — directly spoken of again' (d'Albertis 2007:'Life and Letters' 18; see also Bonaparte 29-30, 195-96; Hyde; Uglow 54).

The biographical line of criticism is helpful in identifying some of the personal reasons for Gaskell's literary preoccupation with mariners and their environs. It furthermore begins to detect Gaskell's understanding of the sea as liminal space, enabling deep, reflective thought away from the material transience of industrialized places. Even the sailor, as a figure of disappearance and return, is transitory in contrast to the waters on which he travels. Of course, such an understanding of the sea was not Gaskell's alone. Nor did it stem purely from her private, intuitive grief. It was rather informed by various long-standing cultural constructions of the sea, as well as more recent cultural and material developments. In this chapter I situate Gaskell's writing on the waterfront in the cultural history of 
seaside tourism in the mid-nineteenth century, of which Gaskell's own holiday experiences provide valuable illumination. I recall the social debates that attended the rise of the beach holiday and examine their particular significance for women. Turning the spotlight away from the sailor-heroes, and onto the waterfront peoples and individuals they leave behind, I argue that in Gaskell's writing the waterfront shapes not only men's but also women's lives, its construction as liminal space enabling the latter to experience to some extent moments of self-contemplation, and even selfassertion, which are limited in other locales.

\section{$\underline{\text { Gaskell's Sailors }}$}

Sailors abound in Gaskell's fiction. Yet whether it is Will Wilson in Mary Barton (1848), "Poor Peter" in Cranford (1853), Frederick Hale in North and South, Frank Wilson in 'The Manchester Marriage' (1858), or Charley Kinraid in Sylvia's Lovers, they make sudden exits. They furthermore often make ill-fated or incomplete returns: Peter comes home late in life; Hale must live in exile; Frank and Kinraid return to find their lovers have seemingly abandoned them, and their former homes are alien to them. Suicide proves the only release for Frank. Seamen's romantic dispositions and melodramatic forms of self-expression push them to the margins of narratives in which more cerebral characterisation takes precedence: Wilson's yarn-spinning and salt-water colloquialisms leave him humorously at odds with Job Leigh (but give melodramatic eloquence to his testimony at his cousin's trial); the Byronic portrait of the mutineer Hale contrasts his sober, pragmatic sister; Kinraid's melodramatic heroism is pitched against the tragic, self-abnegating emergence of Philip Hepburn as the hero in the final volume of Sylvia's Lovers. Seafaring exploits, moreover, are generally described in sailors' yarns or in textual fragments that lack the authority attributable to other characters' reported speeches, or the words of a narrator. Hale's mutiny, for example, recorded in biased newspaper reports that are glossed by his grieving mother, or Frank's account of his shipwreck. For all their magnetism, then, Gaskell's sailors are illusory heroes. Painted in romantic and melodramatic hues, they feel 'unrealistic and outmoded', as Stefanie Markovits has said of Hale (480). If as Patsy Stoneman argues the domestic sphere is crucial to the formation of positive, nurturing masculine identity in Gaskell (esp. 50-53), then the mobility and consequent lack of belonging of these 
characters explains their peripheral status, stalling characterisation, and fragmented narratives. The sailor returns home and experiences the uncanny, only to become an embodiment of the uncanny.

The focus of Gaskell's maritime writing is the coastal society from which the traveller departs. As sailors disappear beyond the representational horizon, their communities and loved ones remain in narrative focus. It is significant, for example, that in a novel so concerned with labour exploitation as Mary Barton the reader learns almost nothing about maritime work. Rather, the emotional travails of seafarers' mothers such as Alice Wilson and Mrs Sturgis receive attention. To some degree the absent mariner finds his way into the home and the main plot through the reminiscences of loved ones, but his function there is to highlight a lack or absence in the domestic realm. The upshot is that Gaskell, especially in her 'condition-of-England' fictions, contributes to what Allan Sekula describes as 'the forgetting of the sea' as a space of ongoing capitalist exchange in mid-nineteenth century literature and art as the 'condition of England' was defined in terrestrial terms $(45-54)$.

Perhaps this concern with sailors' families and waterfront communities, rather than sailors' deep-sea journeys, explains why, with the exception of John Peck's Maritime Fiction: Sailors and the Sea in British and American Novels, 1719-1917 (2001), studies of maritime literature and culture have said next to nothing about Gaskell. Research in this field continues to overlook cultural production at the water's edge. Indeed, in her efforts to read maritime literature on its own terms, not as allegories of society on dry-land, Margaret Cohen arguably under-emphasizes the importance of the littoral in many of the texts examined in The Novel and the Sea (2010). Concentrating upon the representation of seafaring 'craft', Cohen's work and other new 'Oceanic studies' of literature tend to recycle and expand upon long-established definitions and canons of 'maritime literature', in which first-hand experiences of deep-sea voyaging are privileged. Inevitably the focus of this field is upon masculine perspectives, traditions, and societies. To comprehend what Gaskell offers to this field entails drawing upon the work of cultural historians such as Isaac Land and Paul A. Gilje that highlights the primacy of the waterfront as a space in which not only men but also women lived and worked with, and wrote about, the sea. 


\section{To the Seaside}

In the years that Gaskell wrote, many of the British waterfront spaces to which she travelled were undergoing economic, social, and cultural change, as parts of the coast were transformed into places of recreation par excellence.${ }^{1}$ In the late eighteenth and early nineteenth century the main reason, besides work, for travel to the seaside had been curative, but while the health benefits of a beach holiday continued to be claimed in resort advertising in the middle of the 1800s, increasingly the coast was identified as a place for pleasure. The spread of the railways made the shore accessible to the growing number of urban dwellers, enabling the increase in middle-class tourism from around the 1840 s. $^{2}$ The beach then promised release and refreshment to self-consciously industrious Victorians jaded by urban living. This recreational mobility was conceived of as an antidote to bounded, responsible, sometimes even dreary, existence in the home, yet the extent to which it genuinely afforded such a release is debatable. That the railway allowed holidaymakers to travel in greater numbers, more often, and for shorter spells — even day trips — is a clue that the coastal 'getaway' was not immune to those forces of industrialisation (massification, acceleration, standardisation, routinisation) that it was intended to evade. Moreover, the kinds of recreational escape that the beach offered were carefully delimited. Mid-nineteenth-century writings about coastal recreation warn against indolence by promoting amateur-scientific, antiquarian, and sporting activities alongside aesthetic appreciation of the sublime natural environment. Such pastimes were envisaged not only to keep middle-class minds healthily busy, but also to enable continuing spiritual development: beachcombing guides by Charles Kingsley and Phillip H. Gosse promoted 'themes dear to contemporaries, such as the way the natural world revealed close connections between religion, science and art' (Hassan 32). They maintained the identification of the sea as a profound space, 'as close an approximation of the infinite as the visible, physical world can provide', which Christopher Connery traces back to ancient times (508). Religious and aesthetic contemplation allowed for restfulness while nonetheless meeting the demand for self-improving activity.

\footnotetext{
${ }^{1}$ See Walton; Hassan (31-42); Payne.

2 This chapter confines its discussion to the middle-class demand that drove the expansion of seaside tourism in the mid-nineteenth century. For discussion of the increasing mid- to late-nineteenth century demand for coastal recreation among the working classes, and anxious middle-class responses thereto, see Walton (25-40, 188-90). On the broader impact of the railways on British society, see the chapter in this volume by ??.
} 
John K. Walton finds, however, that while 'improving' commentators stressed the need for robust and educative activity, '[m]ost middle-class holidaymakers in most mid-Victorian resorts spent their time on the beach, promenade and pier, surrounded by their children.... [M]ost of the time was devoted to the idleness which was deplored by the serious-minded' (166-67). On the typical middleclass family seaside holiday of the mid nineteenth century, the mother and children would take extended leave at the coast with the paterfamilias joining them at weekends. Children would spend much of their time in the company of nannies (Walton 24). Domestic arrangements tended to be upheld. Walton comments that 'perhaps the most important function of the seaside holiday was to display the stability and affluence of the Victorian middle-class family' (41). Even so, if Gaskell's experiences are at all representative, holidaying at the seaside afforded middle-class women some degree of remedial distance from the strictures of domesticity and thus a space for contemplation. Gaskell's personal correspondence offers glimpses of her particular balance of responsibilities, work, and amusement at the seaside. The Gaskells took several family holidays on the British coast, above all at Morecambe Bay on England's North-West shores. Gaskell writes anxiously on occasion of the need for a coastal holiday to replenish the health of her husband or one of her daughters. Of one trip, Gaskell states to her daughter, Marianne: 'one object of our summer change is health. ${ }^{3}$ Elsewhere, she writes of her forthcoming holiday with her daughters: 'we shall remain for six weeks, and all get as strong as horses'. ${ }^{4}$ But the beach also was sought for pleasure. In personal correspondence she describes the fishing village of Silverdale - 'a little dale running down to Morecambe Bay, with grey limestone rocks on all sides, which in the sun or moonlight, glisten like silver', ${ }^{5}$ which became the Gaskell's 'regular holiday home' (Uglow 146) — fondly, if condescendingly, as a primitive departure from modernity. Silverdale is described as 'so wild a place' and 'a charming primitive desert' that catered only for 'the rudest and most primitive life you ever met with' ${ }^{6}$ It provided chances for the

\footnotetext{
${ }^{3}$ Gaskell to Marianne Gaskell, [? Late April 1852], in Letters, L120.

${ }^{4}$ Gaskell to Charles Eliot Norton 10 [and 14] May 1858, in Letters, L394.

${ }^{5}$ Gaskell to Lady Kay-Shuttleworth, 16 July [?1850], in Letters, L120.

${ }^{6}$ Gaskell to Norton, 10 [and 14] May 1858, p. 504; Gaskell to F.J. Furnivall, 17 June 1858, in Letters, L399; Gaskell to Harriett Bright, June 22 [?1858], in Further Letters, 294-95. Silverdale was nonetheless always enjoyed, in contrast to one trying holiday at Sea Scale, West Cumbria, where severe weather made the rented accommodation feel rather too rickety. See Gaskell to Marianne Gaskell, [?9 October 1857], in Letters, L376a.
} 
children 'to learn country interests, and ways of living and thinking. ${ }^{7}$ It was furthermore a place in which her straight-laced husband was able to unwind. ${ }^{8}$

The Gaskells partook of typical Victorian seaside pastimes such as sightseeing, sketching, and walking. The company of one or more of her children, and sometimes their nannies, her husband, extended family, or friends, not to mention correspondence with absent loved ones and acquaintances, meant that for Elizabeth Gaskell domestic obligations were always in tow. Correspondence by Gaskell and her circle suggests the writer experienced similar struggles to find free time on holiday as at home (see Uglow, 164, 301-2). Nevertheless, the waterfront proved highly productive for Gaskell's writing. The early works 'The Sexton's Hero' (1847) and 'The Moorland Cottage' (1850) took inspiration from Silverdale. As its coastal settings and sea symbolism testify, much of Ruth was written, in the summer of 1852, in a Silverdale top-level drawing room with 'views all round, of the coast and bays to the south, the open sea to the west and the hazy Lakeland mountains to the north and east' (Uglow 302). Famously, Gaskell undertook primary research in Whitby in late 1859 while conceiving of the work that would become Sylvia's Lovers. With the holidaymaking industriousness often advised in Victorian guidebooks, she combined pleasure with work, taking her daughters on fact-finding and sight-seeing trips. When Gaskell faltered two-thirds of the way into writing Sylvia's Lovers, a trip to Silverdale got the book back on course (Uglow 481-85; 498).

The fiction itself most eloquently testifies to the importance of the sea and seaside in developing Gaskell's ideas about not only place, but also character, fate and circumstance, history, and indeed the novel form. As Hughes and Lund argue, the narrative structure of Sylvia's Lovers observes the rhythms of nature, including those of the sea. Kinraid's movements between presence and absence, life and death, reflect the ebb and flow of existence, the sea's cruelty as well as its power to renew $(51-52 ; 64)$. I will proceed to demonstrate that besides upholding the Victorian view of the sea as contemplative space, Sylvia's Lovers and other novels further resonate with the Victorian

\footnotetext{
${ }^{7}$ Gaskell to Lady Kay-Shuttleworth, 16 July [?1850].

8 'Papa does not like the idea of having a stranger in the house in holiday time when you know he likes to play pranks, go cockling etc etc. and feel at liberty to say or do what he likes.' Gaskell to Marianne Gaskell, 4 May 1852, in Letters, L122a. The fullest descriptions of the Gaskell holidays at Silverdale are in letters to Charles Eliot Norton, 10 [and 14] May 1858, and 25 July [1858], in Letters, L394, and L401, respectively; and to Harriett Bright, June 22 [?1858], in Further Letters.
} 
debates on appropriately industrious and self-improving forms of seaside leisure, and with notions of respite from city living. They do so in part by reflecting Gaskell's regard of coastal settlements such as Silverdale as rustic throwbacks to bygone days (a view that continues to inform tourist advertising of seaside holidays in northern England).

Besides representing the coast as a place apart from industrial development, this rustic depiction of the maritime sphere also is determined by, or perhaps informs, the historical setting of Sylvia's Lovers. The novel is set in the 1790s. Its historical perspective is made apparent throughout by the narrator's interjections, often to comment on cultural and social differences between the present from which the tale is narrated and the past that it describes. Finally, in the epilogue, the narrator is identified as a holidaymaker with antiquarian interests in the present-day Monkshaven, a fictional substitute for Whitby. Sylvia's Lovers thus revisits a narrative form first adopted by Gaskell in one of her earliest short stories, 'The Sexton's Hero', in which a tale of Christian self-sacrifice on 'the Sands' of Morecambe Bay is heard by two male tourists. In contrast to the narrator of Sylvia's Lovers, the framing interlocutors of 'The Sexton's Hero' seem unmoved by the sexton's memories. The story ends abruptly as the tourists, 'having rested sufficiently, rose up, and came away.' (110) The reader learns little about the narrator of Sylvia's Lovers other than that her time on vacation has been spent (in comparable fashion to Gaskell's spell in Whitby) learning from locals the story of Sylvia, Philip and Kinraid. The narrator notes Sylvia's tale has been warped by 'popular feeling' in such a way as to misrepresent the former as the typically unfaithful sailor's wife of melodramatic lore (502). As Marion Shaw argues in her authoritative studies of this novel, the narrator thus identifies her role as the realist chronicler of an otherwise forgotten woman's history ('Elizabeth Gaskell, Tennyson and the Fatal Return' 52-53; 'Sylvia's Lovers').

While the novel seeks to recover the truth about Sylvia beyond 'popular feeling', part of the complexity of Sylvia's Lovers arises from Gaskell's, or the narrator's, refusal simply to discredit the songs and chanteys, yarns, supernatural beliefs, dreams, and other cultural fabric through which Sylvia's story has been transformed. Instead, lore is understood as the means by which the people of Monkshaven reassert their values in spite of the broader imperialist and capitalist forces that endanger them, namely the Napoleonic Wars and the transformation of the Monkshaven economy. As a 
holiday-maker, the narrator of Sylvia's Lovers would appear to exist at an end-point in the economic developments that have transformed Monkshaven into 'a rising bath place' (502). She potentially encapsulates the modernity that threatens to sever these coastal peoples from their history and culture. This narrator, however, embodies the conscientious mid-Victorian tourist, and this informs her narrative style. Rather than simply correcting the historical record, she converses with the locals, recovers fragments of the local culture, and weaves them into the narrative. Famously, in the refrain, 'And the waves kept lapping on the shelving shore', which repeats (with small variations) throughout the final chapter, Gaskell knowingly returns the fiction of Phillip, Sylvia, and Kinraid, to its roots in the psalms, hymns, and songs that once had roused the people. ${ }^{9}$ The 'realism' of Sylvia's Lovers is a fidelity to the Monkshaven people's understanding of reality, not a disinterested attempt to record observable reality.

The culture that Gaskell seeks to preserve in Sylvia's Lovers is one formed through its close and profound relation to the sea. As a sign of her closeness to and comprehension of Monkshaven society, the narrator too hears 'the waves come lapping on the shelving shore' (502), a sound that is 'the only enduring connexion' between the past and the present, but, as J.M. Rignall observes, 'one that remains inscrutable, revealing nothing but the mutability and transience of mankind' (27). The unfathomable immensity of 'the great deep' (14) is a perpetual reminder to Monkshaven society of the transience of the rise modern trade in the town, and even of war- 'that buying and selling, eating and marrying, even life and death, were not all the realities of existence' (64; see also 75, 213; Rignall 26). As her chosen husband and her father are taken from her in the fall-out of war, leaving her prey to the advances of her prosperous shopkeeper cousin, Sylvia's fate is defined by historical circumstance. Communion with the sea provides her with sanctuary - to the point that her husband Philip develops a kind of hydrophobia, growing 'jealous of [Sylvia's] love for the inanimate ocean' (360), which she associates with the lost Kinraid. While Sylvia's romantic understanding of Kinraid proves to be illusory, the novel does not undermine her or other characters' emotional investment in the sublime element with which he is associated. Rather, the sea is a powerful medium through which spiritual and other forms of restoration of the self are possible.

\footnotetext{
${ }^{9}$ For further analysis see Uglow 505-28, esp. 512-13.
} 


\section{The Sea and the Self}

After the final repetition of 'the waves come lapping on the shelving shore', the narrator continues by quoting Revelation: "And so it will be until "there shall be no more sea"' (502). In doing so, she recalls one of the key texts in the discursive construction of 'the ocean as an antithetical element or object', as charted by Connery (494). The biblical text speaks prophetically of the new heaven and the new Earth, in which 'there shall be no more sea.' Gaskell's allusion to it is a reminder of the religious underpinnings of nineteenth-century travel to the sea for bodily and psychic reparation. Its vision of a new, or re-formed, physical realm—a space without boundaries—perhaps resonates with Gaskell because of her conception of the waterfront as a space for personal renewal, including women's discovery, or rediscovery, of their inner resources. Non-residents of the coast such as Mary Barton, Ruth Hilton and Margaret Hale all join Sylvia in experiencing it as a site of personal reckoning, where past and present are brought into some kind of focus. '[T]he hard, echoing sands' and 'the ceaseless murmur of the salt sea waves' reflect Ruth Hilton's turmoil in her waterfront confrontation with Bellingham in Ruth (243). As with Mary Barton, whose turmoil regarding Jem's murder charge forces her to venture to Liverpool, culminating in a boat voyage up the Mersey, which leads to her physical and mental collapse, Ruth's very sanity will be tested by her foray to the coast. Ruth travels to the fictional Abermouth in her capacity as governess to the ailing Emma Bradshaw. There, she has an ill-starred reunion with Bellingham. ${ }^{10}$ Both characters at this time assume false identities: to escape the stigma of her fallenness, Ruth passes as the widow Mrs. Denbigh, while Bellingham reinvents himself as Mr. Donne. The timeless, changeless sea stands in contrast to two social chameleons. Yet Ruth proves herself to be uncorrupted, rejecting Bellingham's proposal of marriage upon recognising that 'to go back into sin' by returning to Bellingham would be a more 'awful corruption' than '[t]he errors of my youth' (247). At this moment of self-understanding she is granted what Angus Easson identifies as a 'Wordsworthian epiphany' (xx-xxi): a glorious sunset

\footnotetext{
${ }^{10}$ For further discussion of this journey see the chapter in this volume by Katherine Inglis.
} 
which renews her strength (250-51). The sea, the sun, and the God with which they enable closeness, are on Ruth's side.

Overseeing all on the earthly plain is the fisherman, Stephen Bromley, who watches Ruth and Bellingham from afar while tending to his nets. Ruth feels that despite his reputation as 'a very desperate, violent man' (247) Bromley, who is known to her by name, will protect her from Bellingham's passion. As a minor character, Bromley is figured in appreciative if belittling terms as a representative of the briny but steadfast peoples that provided local colour for visitors to the seaside. But he offers more to Ruth than mere colour because of their implied kinship, which is established by the parallel between the fisherman's geographical marginality and Ruth's mental liminality.

Bromley's minorness and his uncanny characterisation (we learn almost nothing about him other than that he is knowable, predictable) is paradoxically the indicator of these unspoken bonds: as with Ruth, he has uncharted depths.

Time spent by the sea again leads to personal resolution in North and South. Throughout this novel, Margaret Hale plays a complex mediatory role in the transmission of ideas between ship and shore. She learns from her brother's mutiny on HMS Russell that '[1]oyalty and obedience to wisdom and justice are fine; but it is finer to defy arbitrary power, unjustly and cruelly used - not on behalf of ourselves, but on behalf of others more helpless.' (127; see also 307) Margaret then applies this moral in lying to the police to protect the 'helpless' Frederick, and in urging Thornton to become a wise and just master to end the conflict that threatens to embroil Milton-Northern. Yet it would be possible to overstate Frederick's influence upon Margaret. It is the latter, after all, who provides the most eloquent interpretations of the mutiny, including the above quotation. She is more evidently the author of Frederick's Byronic image than he is the inspiration for her actions. Moreover, Margaret reaches her key decision to return to Milton and work alongside Thornton during her one of her own firsthand encounters with the sea.

In North and South, observes Hilary M. Schor, 'the heroine need not leave England to attain her wider vision' (124). The vision that marks Margaret as a heroine is indeed reflected in her decisions not to travel — to Corfu, for instance, to visit Edith, as her father suggests (341) — and to remain ultimately committed to life in Milton. In these ways she contrasts positively with the 
decadent émigré Edith. And yet as ??? explores in detail in this volume, Margaret does travel. Among her various journeys are two to England's coasts. Early in the novel, prior to arriving in Milton, she ventures to Heston with her parents; toward its conclusion she joins Aunt Shaw and the Lennoxes at Cromer. The positioning of these two journeys at opposite ends of the narrative is important to understanding their meanings for Margaret's character development. At Heston, Margaret feels and thinks little more than Mrs. Hale when the latter looks toward 'the pleasure and delight of going to the seaside' (57). Heston provides her with little more than 'rest':

There was a dreaminess in the rest, too, which made it still more perfect and luxurious to repose in. The distant sea, lapping the sandy shore with measured sound; the nearer cries of the donkey-boys; the unusual scenes moving before her like pictures, which she cared not in her laziness to have fully explained before they passed away;.. the white sail of a distant boat turning silver in some pale sunbeam:-it seemed as if she could dream her life away in such luxury of pensiveness, in which she made her present all in all, from not daring to think of the past, or wishing the contemplate the future. (65-66)

Historically, the waterfront had been the space in which maritime labour became visible to nonseafarers. It was then transformed by tourism into the space of recreational diversions from labour for the middle and working classes (Lencek and Bosker 129). Margaret's experience of Heston is testament to the modern tourist beach's ability to de-materialize experience, and erase history, be it personal or social, in the promotion of indolent pleasure. Margaret joins 'the ignoble army of idlers' whose (in)activities at the beach were but 'the life-in-death in which thousands spend the golden weeks of summer', to the disdain of Kingsley $(1,2)$. The passage, then, records the difficulty for middle-class women restricted to tourist experience of the waterfront in perceiving such problems of labour at sea as Frederick encounters. As Rosemarie Bodenheimer writes, 'Margaret's struggles to define her life is ... a battle against forms of idleness', to which women in this novel, more than men, are prey (63).

The passage describing Margaret's time at Heston contrasts that at Cromer. Here, Margaret joins other heroines such as Ruth and Sylvia in reflecting upon the past, and deciding on the future, in 
the mental space she finds at the waterfront. Markovits likens the passage's romantic description of the sea's 'eternal psalm' to Matthew Arnold's 'Dover Beach' (1867), suggesting that the poem's retreat from a world-gone-mad into the security of interpersonal relations shares the direction of Gaskell's thought in North and South (490). This comparison helps establish the world-weariness of Margaret at this juncture in the narrative. As the passage develops, however, her agency is rekindled. While her relatives indulge in seaside past-times, her time at Cromer 'enabled Margaret to put events in their right places, as to origin and significance, both as regarded her past life and her future. Those hours by the sea-side were not lost, as any one might have seen who had the perception to read, or the care to understand, the look that Margaret's face was gradually acquiring' (495). Edith is no such reader: she attributes the improvement in her cousin's appearance to the new bonnet that she has bought for her. The real reason for Margaret's awakening is that in her time by the sea she determines to reject Henry Lennox and the life of luxury that he offers in order to return to Milton. This spell leads Margaret to her much-quoted attempt 'to settle that most difficult problem for women, how much was to be utterly merged in obedience to authority, and how much might be set apart for freedom in working' (497). In its concern with obedience and authority, Margaret's problem echoes the moral dilemma that she extracts from her brother's mutiny and extends to the Milton strike. And yet, especially in its suggestion of 'freedom in working', this passage is illustrative of the tension between leisure and labour that concerned Victorian writing about the beach holiday, Gaskell's correspondence included. The novel moreover reveals a paradox at the heart of this tension, which is that pleasurable diversion from everyday responsibilities of work and status could lead to earnest contemplation of these very same aspects of social identity - a point which seems to be not far from the surface of each of the novels by Gaskell discussed above.

In her interpretation of Sylvia's Lovers, Shaw identifies the importance of the sea as the liminal space in which Sylvia comes to terms with her existence. In her own communion with the sea, an appreciation of its endlessly destructive and restorative motions, the narrator of Sylvia's Lovers comes to regard Sylvia's place — or absence —in history. In Ruth and North and South the water's edge is again a crucial space in which scrutiny of the self, nature, and questions of society and morality are brought productively to bear upon one another. These representations of the littoral might 
be seen to anticipate explorations in twentieth-century women's writing. Examples in fiction alone range from the modernism of Kate Chopin in The Awakening (1899), Katherine Mansfield in 'At the Bay' (1922), Virginia Woolf (especially in To the Lighthouse, 1927), and Jean Rhys in Wide Sargasso Sea (1966), to the gothic melodrama of Daphne du Maurier, not least Jamaica Inn (1936) and Rebecca (1938). This relationship between Gaskell and later writers is complicated, however, for as I have shown, in Gaskell's time such deep, impressionistic thinking about the waterfront was closely tied to Christian constructions of the seaside as a space, which, in its sublime power, might aid contemplation of God's plan and the role of the individual within it. Gaskell moreover shares in the mid-Victorian association of sublime seaside experience with morally improving activity: for Ruth, Sylvia, and Margaret to gaze at what Joseph Conrad would later call 'the mirror of the sea' provides but brief respite for lives lived in dutiful industriousness. '[F]reedom in working': Margaret's wish must have struck a chord with Gaskell, who wrote so productively while holidaying on the coast.

\section{Works Cited}

Arnold, Matthew. 'Dover Beach' (1867). The Poems of Matthew Arnold. Ed. Kenneth Allott. London: Longmans, 1965.

Bodenheimer, Rosemarie. The Politics of Story in Victorian Social Fiction. Ithaca, London: Cornell UP, 1988.

Bonaparte, Felicia. The Gypsy-Bachelor of Manchester: The Life of Mrs. Gaskell's Demon. Charlottesville: UP of Virginia, 1992.

Chopin, Kate. The Awakening. Chicago: H.S. Stone, 1899.

Cohen, Margaret. The Novel and the Sea. Princeton, NJ: Princeton UP, 2010.

Connery, Christopher. 'There was No More Sea: The Suppression of the Ocean, from the Bible to Cyberspace.' Journal of Historical Geography 32 (2006): 494-511.

Conrad, Joseph. The Mirror of the Sea: Memories and Impressions. London: Methuen, 1906. 
d'Albertis, Deidre. Dissembling Fictions: Elizabeth Gaskell and the Victorian Social Text. New York: St. Martin's P, 1997.

---. 'The Life and Letters of E.C. Gaskell.' The Cambridge Companion to Elizabeth Gaskell. Ed. Jill L. Matus. Cambridge: CUP, 2007. 10-26.

du Maurier, Daphne (1936), Jamaica Inn. London: Arrow, 1992.

---. (1938) Rebecca. London: Arrow, 1992.

Easson, Angus. (1997). Introduction. Ruth. Ed. Angus Easson. London: Penguin, 2004. vii-xxvi. Gaskell, Elizabeth(1853), 'Cranford'. Cranford and Other Stories. Ed. John Chapple. Ware, Hertfordshire:

Wordsworth, 2006. 23-184.

---. (2000) Further Letters of Mrs. Gaskell. Ed. John Chapple and Alan Shelston. Manchester: Manchester UP, 2003.

---. (1848), Mary Barton Ed. Thomas Recchio. New York: Norton Critical Editions, 2008.

---. (1850), 'The Moorland Cottage'. The Moorland Cottage and Other Stories. Ed. Suzanne Lewis.

Oxford: OUP, 1995.

---. (1855), North and South. London: Penguin, 1994.

---. (1853), Ruth. Ed. Angus Easson. London: Penguin, 2004.

---. (1863), Sylvia's Lovers. Ed. Andrew Sanders. Oxford: Oxford

World's Classics, 1982.

---. The Letters of Mrs. Gaskell. Ed. J.A.V. Chapple and Arthur Pollard. Manchester: Manchester UP, 1966.

---. (1858), 'The Manchester Marriage'. The Moorland Cottage and Other Stories. Ed. Suzanne Lewis. Oxford: OUP, 1995. 227-53.

---. (1847) 'The Sexton's Hero'. The Moorland Cottage and Other Stories. Ed.

Suzanne Lewis. Oxford: OUP, 1995. 101-10. 
Gilje, Paul A. Liberty on the Waterfront: American Maritime Culture in the Age of Revolution.

Philadelphia: U of Pennsylvania P, 2004.

Gosse, Phillip H. Tenby: A Sea-side Holiday. London: John Van Voorst, 1856.

Hassan, John. The Seaside, Health and the Environment in England and Wales since 1800.

Aldershot, Hampshire: Ashgate, 2003.

Hughes, Linda K., and Michael Lund. Victorian Publishing and Mrs. Gaskell's Work. Charlottesville: U P of Virginia, 1999.

Hyde, William J. “"Poor Frederick” and “Poor Peter”: Elizabeth Gaskell’s Fraternal Deviants.' GSJ 9 (1995): 21-26.

Kingsley, Charles. (1855) Glaucus; or, The Wonders of the Shore. Cambridge: Macmillan, 1859.

Land, Isaac. 'Review Essay: Tidal Waves: The New Coastal History.' Journal of Social History 40.3 (2007): 731-43.

Lencek, Lena, and Gideon Bosker. The Beach: The History of Paradise on Earth. New York: Viking, 1998.

Lewis, Michael D. 'Mutiny in the Public Sphere: Debating Naval Power in Parliament, the Press, and Gaskell's North and South.' Victorian Review 36.1 (2010): 89-113.

Mansfield, Katherine. 'At the Bay.' The Garden Party and Other Stories. New York: Alfred A. Knopf, 1922. 1-58.

Markovits, Stefanie. 'North and South, East and West: Elizabeth Gaskell, the Crimean War, and the Condition of England.' Nineteenth-Century Literature 59.4 (2005): 463-93.

Morse, Deborah Denenholz. 'Mutiny on the Orion: The Legacy of the Hermione Mutiny and the Politics of Nonviolent Protest in Elizabeth Gaskell's North and South.' Pirates and Mutineers of the Nineteenth Century: Swashbucklers and Swindlers. Ed. Grace Moore. Farnham, Surrey: Ashgate, 2001. 117-31.

Payne, Christiana. 'Seaside Visitors: Idlers, Thinkers and Patriots in Mid-nineteenth-century Britain'. Water, Leisure and Culture: European Historical Perspectives. Ed. Susan C. Anderson and Bruce H. Tabb. Oxford: Berg, 2002. 87-104.

Peck, John. Maritime Fiction: Sailors and the Sea in British and American Novels, 1719-1917. 
Basingstoke, Hampshire: Palgrave Macmillan, 2001.

Rhys, Jean (1966), Wide Sargasso Sea. Harmondsworth: Penguin, 1968.

Rignall, J.M. 'The Historical Double: Waverley, Sylvia's Lovers, The Trumpet-Major.' Essays in Criticism 34.1 (1984): 14-32.

Schor, Hilary M. Scheherezade in the Marketplace: Elizabeth Gaskell and the Victorian Novel. Oxford: OUP, 1992.

Shaw, Marion. 'Elizabeth Gaskell, Tennyson, and the Fatal Return: Sylvia's Lovers and Enoch Arden' GSJ 9 (1995): 43-54.

---. 'Sylvia's Lovers, then and now' GSJ 18 (2004): 37-49.

Stoneman, Patsy. Elizabeth Gaskell. Brighton: Harvester Press, 1987.

Uglow, Jenny (1993). Elizabeth Gaskell: A Habit of Stories. London: Faber and Faber, 1999.

Walton, John K. The English Seaside Resort: A Social History, 1750-1914. Leicester: Leicester UP, 1983.

Woolf, Virgina. (1927). To the Lighthouse. London: Hogarth P, 1990. 